Article

\title{
Ethnobotanical Survey of Wild Edible Fruit Tree Species in Lowland Areas of Ethiopia
}

\author{
Tatek Dejene ${ }^{1}\left(\mathbb{D}\right.$, Mohamed Samy Agamy ${ }^{2} \mathbb{(}$, Dolores Agúndez ${ }^{3}\left(\mathbb{D}\right.$ and Pablo Martin-Pinto ${ }^{2, *}$ \\ 1 Ethiopian Environment and Forest Research Institute, 30708 Addis Ababa, Ethiopia; tdejenie@yahoo.com \\ 2 Sustainable Forest Management Research Institute, University of Valladolid (Palencia), Avda. Madrid 44, \\ 34071 Palencia, Spain; samym392@yahoo.com \\ 3 INIA-CIFOR, Ecología y Genética Forestal, Carretera de la Coruña km 7.5, 28040 Madrid, Spain; \\ agundez@inia.es \\ * Correspondence: pmpinto@pvs.uva.es; Tel.: +34-979-108-340; Fax: +34-979-108-440
}

Received: 20 December 2019; Accepted: 31 January 2020; Published: 5 February 2020

\begin{abstract}
This study aimed to provide baseline information about wild edible tree species (WETs) through surveying of different ethnic groups in dryland areas in Ethiopia. Here the data about WETs are scant, and WETs status is unexplained under the rampant habitat degradation. Use forms, plant parts used, status, ethnobotanical knowledge, conservation needs as well as those threats affecting WETs were reviewed. The study identified 88 indigenous wild edible plants, of which 52 species were WETs. In most cases, fruits were found as the dominant use part, and they were used as raw but were occasionally cooked and preserved. Roots and bark uses are also reported from Ximenia americana and Racosperma melanoxylon respectively. June, July and August were critical periods observed for food shortage in most of the regions. However, in the Gambella region, food shortages occurred in most months of the year. The respondents in this region suggested that WETs could potentially provide them with enough food to make up for the shortage of food from conventional agricultural crops. From the respondents' perception, Opuntia ficus-indica, Carissa edulis and Ficus vasta were among the most difficult to locate species, and they also received the highest conservation attention. Because of the variety of WETs and existing different threats, a management strategy is required for future conservation, as WETs are vital for the livelihood of local communities and are also necessary to devise a food security strategy for Ethiopia. The lesson obtained could also be useful in other dryland parts in developing countries with similar contexts.
\end{abstract}

Keywords: wild edible tree species; biodiversity; ethnic groups; conservation; food security

\section{Introduction}

More than 700 million people are suffering from hunger worldwide [1]. In some cases, nutritional deficiencies are due to a lack of diversity in the diet [2] and an inadequate supply of micronutrients [3]. In this context, wild forest foods can play an important role as supplements to the staple diet [4-6], by enhancing the diversity of the diet of many rural people in developing countries [7], increasing the nutritional quality of rural diets [8], and supplementing other food sources [5] during drought and famine periods. Thus, in recent years, there has been increasing attention focused on the sustainability of diets $[5,9,10]$ and food systems, which has highlighted the need to conserve species diversity, mainly of forest resources [11,12] in many parts of the world.

Wild edible tree species (WETs) are among the most widely used non-timber forest products and represent an open access source of food and medicine [13], especially for vulnerable social groups. Thus, WETs are an important source of sustenance for many people in developing countries [6,14], improving household food security under normal circumstances as well as during crop scarcity periods [15-17] in 
urban and rural contexts [18]. Furthermore, WETs can represent important sources of income for their users $[19,20]$.

More than 200 tree species have been registered as WETs in Ethiopia, which have been used since antiquity by rural people [21]. The wide range of climatic and edaphic conditions in Ethiopia enables a highly diverse range of WETs to grow in this country [22,23]. However, anthropogenic factors are causing the decline of these natural resources in most habitats [24,25]. Along with these factors, multiple components of climate change are also predicted to be the main drivers of biodiversity [26], with all levels of impact on WETs.

Many of the WETs found in Ethiopia are readily available for their nutritional, medicinal and marketable use $[23,27]$. The use of particular WETs is also determined by culture and location, and they continue to be maintained by cultural preferences and traditional practices. Although the use of WETs in Ethiopia has been investigated in different localities [23], there are still many WETs that are inadequately characterized and neglected by research. This partly explains why the most valuable WETs remain undocumented, particularly in dry forests where there is a relatively large supply of edible products. This situation, thus, greatly undermines their conservation and sustainable utilization. Furthermore, indigenous knowledge about the use of WETs has not been sufficiently documented, leading to a cultural erosion of their uses [28,29]. Consequently, interest in documenting information about wild edible food sources such as WETs in forest systems [30] around the world has increased in recent years. Ethnobiological studies of WETs are important to record information pertaining to the diversity of species used, the relative importance of each species, their different uses by indigenous communities, seasonal availability, and the conservation needs of the identified species, together with their main threats in the dryland areas of Ethiopia.

To enhance our understanding of the management and conservation strategies required for WETs in Ethiopia, we employed mixed methods to investigate different aspects of the same phenomenon [31] and gathered data from rural communities about traditional uses of WETs. We hypothesized that different rural populations would identify different uses for WETs according to their cultural history and locality. We also expected to find that different WETs face specific threats and that the conservation status for the main WETs would vary in each location. Thus, our specific objectives were (i) to identify tree species that provide edible products that are used by rural communities during periods of food shortage across different regions of Ethiopia; (ii) to evaluate the conservation status of the most consumed WETs; and (iii) to identify the main threats to these species and to assess how these threats varied across the studied areas.

\section{Materials and Methods}

\subsection{Characteristics of the Study Areas}

The drylands of Ethiopia consist of arid, semiarid and dry subhumid regions and cover approximately $55 \%$ of the land mass [32]. They are mainly found in the north, east and central areas of the Rift valley and also in the south and southeastern parts of the country, including a very wide and diversified range of agricultural environments. The altitude ranges from -124 to $1500 \mathrm{~m}$ above sea level. Rainfall is low, erratic, and uneven in distribution and ranges from 200 to $700 \mathrm{~mm}$ annually [32]. Soils in many drylands have low organic matter content, are highly eroded and have low fertility. The two main vegetation types in the dryland areas of Ethiopia are Acacia-Commiphora and Combretum-Terminalia deciduous woodlands [32].

This study was conducted in the dry agro-ecological zones found in six administrative regions of Ethiopia: Tigray, Amhara, Oromia, Benishangul Gumuz, Gambella and the South Nations, Nationalities, and Peoples (SNNP) (Figure 1). The inhabitants of these areas are sedentary agriculturists who practice mixed agriculture, crop production and livestock rearing. They commonly practice shifting cultivation and grow sesame, cotton and sorghum. The specific sites (i.e., the Woreda and Kebele) where the surveys were conducted are listed in Tables 1 and 2. 


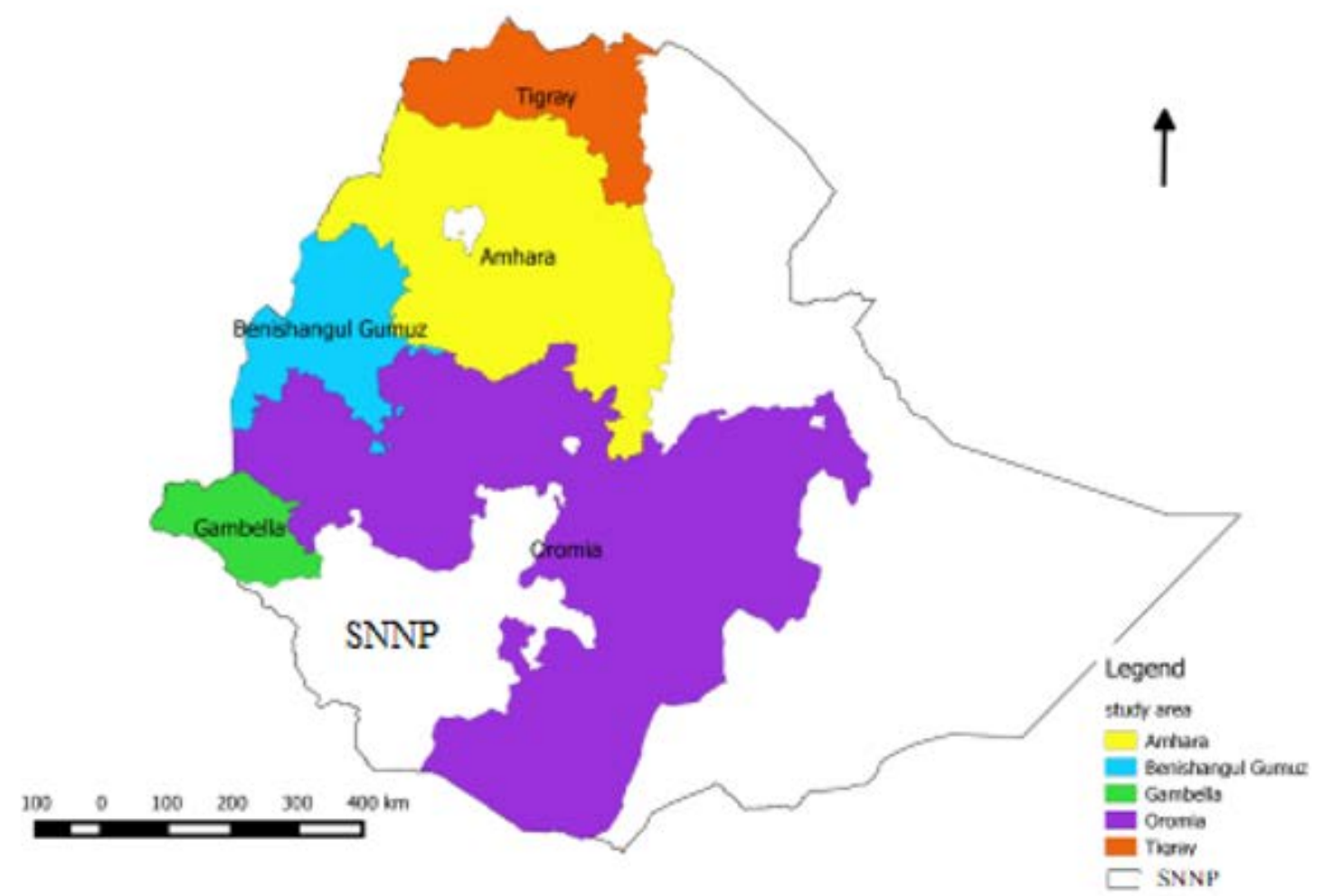

Figure 1. Map of Ethiopia showing the administrative regions that were surveyed in this study.

Table 1. Number of surveys conducted using focus groups and their location.

\begin{tabular}{|c|c|c|c|}
\hline Region & Woreda/Kebele & $\begin{array}{c}\text { Number of Surveys } \\
\text { Conducted in the } \\
\text { Kebele }\end{array}$ & $\begin{array}{l}\text { Total Number of Surveys } \\
\text { Conducted in the Woreda }\end{array}$ \\
\hline Amhara & $\begin{array}{l}\text { Kobo/Gedemeyu } \\
\text { Kobo/Adis Kign }\end{array}$ & $\begin{array}{l}3 \\
3\end{array}$ & 6 \\
\hline Benishangul Gumuz & $\begin{array}{c}\text { Bambasi/Bambisa } \\
\text { Bambasi/Sonka } \\
\text { Debate/Debate } \\
\text { Debate/Parzeit } \\
\text { Homosha/Sherkole } \\
\text { Homosha/Tumet } \\
\text { Mandura/Duhansebeguna } \\
\text { Mandura/Edida }\end{array}$ & $\begin{array}{l}3 \\
3 \\
2 \\
2 \\
3 \\
3 \\
2 \\
2\end{array}$ & 20 \\
\hline Gambella & $\begin{array}{l}\text { Gog/Puchala } \\
\text { Gog/Gongjor } \\
\text { Lare/Ngour } \\
\text { Lare/Nip-nip }\end{array}$ & $\begin{array}{l}3 \\
3 \\
3 \\
3\end{array}$ & 12 \\
\hline Oromia & Dolo Mena/Chirri & 2 & 2 \\
\hline $\begin{array}{l}\text { South Nations, Nationalities and } \\
\text { Peoples Region (SNNPR) }\end{array}$ & $\begin{array}{l}\text { Hammer/Angode } \\
\text { Hammer/Bita }\end{array}$ & $\begin{array}{l}3 \\
3\end{array}$ & 6 \\
\hline Tigray & $\begin{array}{l}\text { Raya Azebo/Kara Adisho } \\
\text { Raya Azebo/Hawelti }\end{array}$ & $\begin{array}{l}3 \\
3\end{array}$ & 6 \\
\hline
\end{tabular}


Table 2. Number of surveys conducted using key informants and their location.

\begin{tabular}{|c|c|c|c|}
\hline Region & Woreda/Kebele & $\begin{array}{l}\text { Number of Surveys } \\
\text { Conducted in the Kebele }\end{array}$ & $\begin{array}{l}\text { Total Number of } \\
\text { Surveys Conducted } \\
\text { in the Woreda }\end{array}$ \\
\hline \multirow{2}{*}{ Amhara } & Kobo/Gedemeyu & 4 & \multirow{2}{*}{9} \\
\hline & Kobo/Adis Kign & 5 & \\
\hline \multirow{9}{*}{ Benishangul Gumuz } & Bambasi/Bambisa & 5 & \multirow{9}{*}{32} \\
\hline & Bambasi/Sonka & 5 & \\
\hline & Debate/Debate & 3 & \\
\hline & Debate/Parzeit & 3 & \\
\hline & Homosha/Sherkole & 5 & \\
\hline & Homosha/Tumet & 5 & \\
\hline & Mandura/Duhansebeguna & 3 & \\
\hline & Mandura/Edida & 3 & \\
\hline & Gog/Puchala & 3 & \\
\hline \multirow{3}{*}{ Gambella } & Gog/Gongjor & 5 & \multirow{3}{*}{18} \\
\hline & Lare/Ngour & 5 & \\
\hline & Lare/Nip-nip & 5 & \\
\hline Oromia & Dolo Mena/Chirri & 1 & 3 \\
\hline South Nations, Nationalities, and & Hammer/Angode & 5 & 0 \\
\hline Peoples Region (SNNPR) & Hammer/Bita & 4 & 9 \\
\hline \multirow{2}{*}{ Tigray } & Raya Azebo/Kara Adisho & 5 & \multirow{2}{*}{10} \\
\hline & Raya Azebo/Hawelti & 5 & \\
\hline
\end{tabular}

\subsection{Data Collection: Sampling Technique and Sample Size}

In this study, both the qualitative and quantitative data collection methods were employed. To collect data, two major primary data collection methods were used. The study was a cross-sectional survey of respondents from 19 Kebeles, the lowest administrative division in Ethiopia. This was supplemented with a total of 52 focus group discussions (Table 1) and 81 key informant surveys (Table 2). The respondents were selected using random sampling methods by ensuring the inclusion of at least $20 \%$ female in the sample. The following selection criteria were used to select the communities in the sampling: (i) a high dependence on agriculture and forestry, (ii) food shortages caused by drought, (iii) a high level of representation of the major ethnic groups and (iv) easy of accessibility of the Kebele.

\subsubsection{Focus Group Discussion}

Focus group discussions were conducted in the studied areas (Table 1). Each focus group consisted of 10 participants, and a total of 520 individuals were involved. These individuals were selected randomly from each study area. The purpose of the focus groups discussion was to generate information on a complete list of food trees for the study areas, which is necessary to estimate proportions of food that are obtained from wild trees and different issues including shortage period, product type collected form the forest, part of the tree used and the pattern of consumption, collection and availability time of the wild foods.

\subsubsection{Key Informant Interview}

The purpose of key informant interviews was to assess threats to important tree species. All key informants were familiar and knowledgeable for the area and the tree species identified in the focus group discussion. Thus, those who were known for their knowledge of the food tree products as food, traditional healers (from the area), local foresters, wood cutters, hunters, market vendors (who sell products obtained from trees) and others were included. Also, these individuals were supposed to have relatively good knowledge about their community situation, local natural resources, the culture of the community and the respective changes in the area.

A face-to-face semistructured questionnaire survey was conducted to collect primary data from the sampled key informants (Table 2). The questionnaire related to the objectives of this study was pretested with 15 randomly selected individuals in each region. Based on the results of the pretest work, 
necessary modifications to the questionnaires were implemented. Enumerators who were knowledgeable about the area were recruited from the study areas. Prior to performing the key informant interviews, the study objectives were explained to the enumerators, and they were trained in the methods of data collection and interviewing techniques. Finally, the survey was conducted on a total of 81 key informants. Hence, they shared their built-up knowledge and experience with the interviewer. The official language in Ethiopia is the Amharic language; however, the local people use their own languages. Thus, the surveys were translated from English to Amharic and from Amharic to local languages. In some cases, an interpreter conducted the surveys to ensure that the meaning of the questionnaires was not changed.

\subsection{Data Analysis}

Descriptive statistics were used to present the basic information obtained from the questionnaires. All the analyses were conducted based on the frequency of responses for each species, referring how many times the species were raised during the focus group discussion and key informant interviews. A final list of food tree species used by respondents was compiled from the questionnaires. The local names of the tree species were identified at their scientific name whenever possible following several keys [23,33-37].Clustering was used for the 30 most frequently used species based on the plant part used and how it was consumed by local communities. The cluster was based on the average linkage between groups. The statistical significance of the distance between groups was obtained by performing a chi square test using SPSS v.20. The chi square test was used for the 15 most frequently used tree species in order to analyze differences based on the following variables: period of food shortage, WETs food availability, ease of locating, conservation practices and regeneration presence. Respondents ranked the effect of different threats on each WETs on a scale of 0 to 4; therefore, Kruskal-Wallis and Mann-Whitney U tests were performed to analyze how the most frequently used species were affected. Data were analyzed using STATISTICA '08 edition software (StatSoft Inc., 1984-2008, the Netherlands).

\section{Results}

\subsection{Diversity of Wild Edible Tree Species}

A total of 88 wild edible plant species were identified by surveyed respondents as being utilized by local communities in the studied dryland areas of Ethiopia. Of these, 52 species belonging to 40 genera and 27 families were identified as WETs (Table 3). The families with the greatest numbers of edible tree species identified by survey respondents were the Malvaceae (five species) and Moraceae (four species), followed by the Boraginaceae, Anacardiaceae, Arecaceae, Rhamnaceae and Rubiaceae, which each had three edible tree species. These families represent about $46 \%$ of the registered taxa. Furthermore, approximately $31 \%$ of families were represented by more than 16 edible species, whereas the remaining $23 \%$ of families were represented by only a single species.

Table 3. List of wild edible species identified in study areas, including their plant part used and consumption form.

\begin{tabular}{|c|c|c|c|c|}
\hline Species & Family & Part Used $^{a}$ & Consumption $^{b}$ & Region $^{c}$ \\
\hline Balanites aegyptiaca Delile & Balanitaceae & $\mathrm{L} / \mathrm{F}$ & Rw & $\mathrm{T} / \mathrm{A} / \mathrm{B} / \mathrm{G} / \mathrm{SN}$ \\
\hline Bauhinia thonningii Schumach. & Fabaceae & B & $\mathrm{Rw} / \mathrm{Pr}$ & $\mathrm{G} / \mathrm{B} / \mathrm{O}$ \\
\hline Borassus aethiopum Mart. & Arecaceae & $\mathrm{F}$ & Rw & G \\
\hline Casimiroa edulis S.Watson & Rutaceae & $\mathrm{F}$ & Rw & B \\
\hline Celtis africana Burm. $\mathrm{f}$. & Cannabaceae & $\mathrm{F}$ & Rw & G \\
\hline Commiphora schimperi Engl. & Burseraceae & $\mathrm{R}$ & Ck & SNNPR \\
\hline Cordia africana Lam. & Boraginaceae & $\mathrm{F}$ & Rw & B \\
\hline
\end{tabular}


Table 3. Cont.

\begin{tabular}{|c|c|c|c|c|}
\hline Species & Family & Part Used $^{\mathrm{a}}$ & Consumption $^{\mathrm{b}}$ & Region $^{c}$ \\
\hline Cordia monoica Roxb. & Boraginaceae & $\mathrm{F}$ & $\mathrm{Rw}$ & $\mathrm{T} / \mathrm{A}$ \\
\hline Cordia sinensis Lam. & Boraginaceae & $\mathrm{F}$ & $\mathrm{Rw}$ & $\mathrm{SN}$ \\
\hline Crateva adansonii DC. & Capparaceae & $\mathrm{R}$ & $\mathrm{Ck}$ & G \\
\hline Diospyros mespiliformis Hochst.ex A.DC. & Ebenaceae & $\mathrm{F}$ & $\mathrm{Rw}$ & $\mathrm{B} / \mathrm{G}$ \\
\hline Dovyalis abyssinica (A. Rich.) Warb. & Flacourtiaceae & $\mathrm{F}$ & $\mathrm{Rw}$ & B \\
\hline Ficus sur Forssk. & Moraceae & $\mathrm{F}$ & Rw & $\mathrm{T} / \mathrm{B} / \mathrm{G} / \mathrm{O} / \mathrm{SN}$ \\
\hline Ficus sycomorus L. & Moraceae & $\mathrm{F}$ & Rw & $\mathrm{B} / \mathrm{G}$ \\
\hline Ficus vasta Forssk. & Moraceae & $\mathrm{L} / \mathrm{F}$ & Rw & $\mathrm{T} / \mathrm{A}$ \\
\hline Flueggea virosa (Roxb. ex Willd.) Royle & Phyllanthaceae & $\mathrm{L}$ & $\mathrm{Ck}$ & G \\
\hline Gardenia ternifolia Schumach. \& Thonn. & Rubiaceae & $\mathrm{F}$ & $\mathrm{Rw}$ & $\mathrm{B}$ \\
\hline Grewia bicolor Juss. & Malvaceae & $\mathrm{F}$ & Rw & SN \\
\hline Grewia ferruginea Hochst. & Malvaceae & $\mathrm{F}$ & Rw & B \\
\hline Grewia velutina (Forsk.) Lam. & Malvaceae & $\mathrm{F}$ & Rw & B \\
\hline Grewia villosa Willd. & Malvaceae & $\mathrm{L} / \mathrm{F}$ & Rw & $\mathrm{T} / \mathrm{A}$ \\
\hline Hyphaene thebaica Mart. & Arecaceae & $\mathrm{F}$ & Rw & G \\
\hline Lannea humilis Engl. & Anacardiaceae & $\mathrm{R}$ & $\mathrm{Ck}$ & $\mathrm{SN}$ \\
\hline Maytenus senegalensis (Lam.) Exell & Celastraceae & $\mathrm{F}$ & $\mathrm{Rw}$ & $\mathrm{SN}$ \\
\hline Mimusops kummel Bruce ex A.DC. & Sapotaceae & $\mathrm{F}$ & $\mathrm{Rw}$ & $\mathrm{B} / \mathrm{G}$ \\
\hline Mitragyna inermis (Willd.) K.Schum. & Rubiaceae & $\mathrm{F}$ & Rw & B \\
\hline Morus mesozygia Stapf & Moraceae & $\mathrm{F}$ & Rw & $\mathrm{B}$ \\
\hline Nauclea latifolia Sm. & Rubiaceae & $\mathrm{F}$ & $\mathrm{Rw}$ & $\mathrm{G}$ \\
\hline Olea capensis L. & Oleaceae & $\mathrm{F}$ & Rw & $\mathrm{A} / \mathrm{B}$ \\
\hline Oncoba spinosa Forssk. & Flacourtiaceae & $\mathrm{F}$ & Rw & $\mathrm{B} / \mathrm{G} / \mathrm{O}$ \\
\hline Opuntia ficus-indica Mill. & Cactaceae & $\mathrm{F}$ & Rw & $\mathrm{T} / \mathrm{A}$ \\
\hline Phoenix reclinata Jacq. & Arecaceae & $\mathrm{L} / \mathrm{F}$ & $\mathrm{Rw} / \mathrm{Ck}$ & $\mathrm{B}$ \\
\hline $\begin{array}{c}\text { Pistacia lentiscus subsp. emarginata (Engl.) } \\
\text { Al-Saghir }\end{array}$ & Anacardiaceae & $\mathrm{F}$ & Rw & $\mathrm{B}$ \\
\hline Racosperma melanoxylon (R.Br.) Pedley & Fabaceae & $\mathrm{F}$ & $\mathrm{Rw}$ & $\mathrm{G} / \mathrm{O}$ \\
\hline Rumex nervosus Vahl & Polygonaceae & $\mathrm{F}$ & Rw & A \\
\hline Saba comorensis (Bojer) Pichon & Apocynaceae & $\mathrm{F}$ & Rw & $\mathrm{B}$ \\
\hline $\begin{array}{c}\text { Searsia natalensis (Bernh. ex Krauss) } \\
\text { F.A.Barkley }\end{array}$ & Anacardiaceae & $\mathrm{F}$ & $\mathrm{Rw}$ & $\mathrm{T}$ \\
\hline Strychnos innocua Delile & Loganiaceae & $\mathrm{F}$ & Rw & B \\
\hline Strychnos spinosa Lam. & Loganiaceae & $\mathrm{F}$ & Rw & B \\
\hline Syzygium guineense DC. subsp. guineense & Myrtaceae & F & Rw & $\mathrm{B} / \mathrm{O}$ \\
\hline Tamarindus indica $\mathrm{L}$. & Fabaceae & $\mathrm{F}$ & Rw & $\mathrm{B} / \mathrm{G} / \mathrm{O} / \mathrm{SN}$ \\
\hline Vitellaria paradoxa C.F.Gaertn. & Sapotaceae & $\mathrm{F} / \mathrm{B} / \mathrm{S}$ & $\mathrm{Rw} / \mathrm{Ck} / \mathrm{Pr}$ & $\mathrm{G}$ \\
\hline Vitex doniana Sweet & Verbenaceae & F & Rw & $\mathrm{B} / \mathrm{G}$ \\
\hline Ximenia americana $\mathrm{L}$. & Olacaceae & $\mathrm{F}$ & $\mathrm{Rw}$ & $\mathrm{A} / \mathrm{B} / \mathrm{G} / \mathrm{O} / \mathrm{SN}$ \\
\hline Ximenia caffra Sond. & Olacaceae & $\mathrm{F}$ & Rw & $\mathrm{B} / \mathrm{O}$ \\
\hline Ziziphus abyssinica Hochst. ex A.Rich. & Rhamnaceae & $\mathrm{F}$ & Rw & G \\
\hline Ziziphus mucronata Willd. & Rhamnaceae & $\mathrm{F}$ & $\mathrm{Rw}$ & SN \\
\hline Ziziphus spina-christi (L.) Desf. & Rhamnaceae & F & $\mathrm{Rw}$ & All \\
\hline
\end{tabular}

${ }^{a}$ Part used: bark (B), fruit (F), leaf (L), root (R) and seed (S). ${ }^{\mathrm{b}}$ Consumed raw (Rw), cooked (Ck) or preserved (Pr). ${ }^{\mathrm{c}}$ Regions: All, in all regions, Gambella $(\mathrm{G})$, Tigray $(\mathrm{T})$, Benishangul Gumuz (B), Amhara (A), Oromia $(\mathrm{O})$ and South Nations, Nationalities and Peoples (SN).

Based on the plant parts used and the method of consumption of the 52 WETs identified by respondents, the 30 most commonly reported WETs by the respondents in all regions were categorized into different groups (Figures 2 and 3). The edible plant parts that were commonly used were the fruit, leaf, bark, root and seed. Although the fruit of all 30 of the most commonly reported species was utilized by respondents, the cluster analysis categorized these WETs into two main groups and two independent species (Figure 2). The first main group comprised 18 WETs that were mainly used for their fruit. However, respondents indicated that the root of Ximenia americana and Tamarindus indica and that the bark of Ficus sur, Celtis africana and Racosperma melanoxylon were also used by local communities. The second main group comprised 10 species that were grouped together based on the consumption of their leaves. In addition, the bark of Balanites aegyptiaca was also reported as 
potential food. Flueggea virosa and Vitellaria paradoxa, which are used for their leaves and edible fat seed, respectively, were grouped independently of the other WETs.

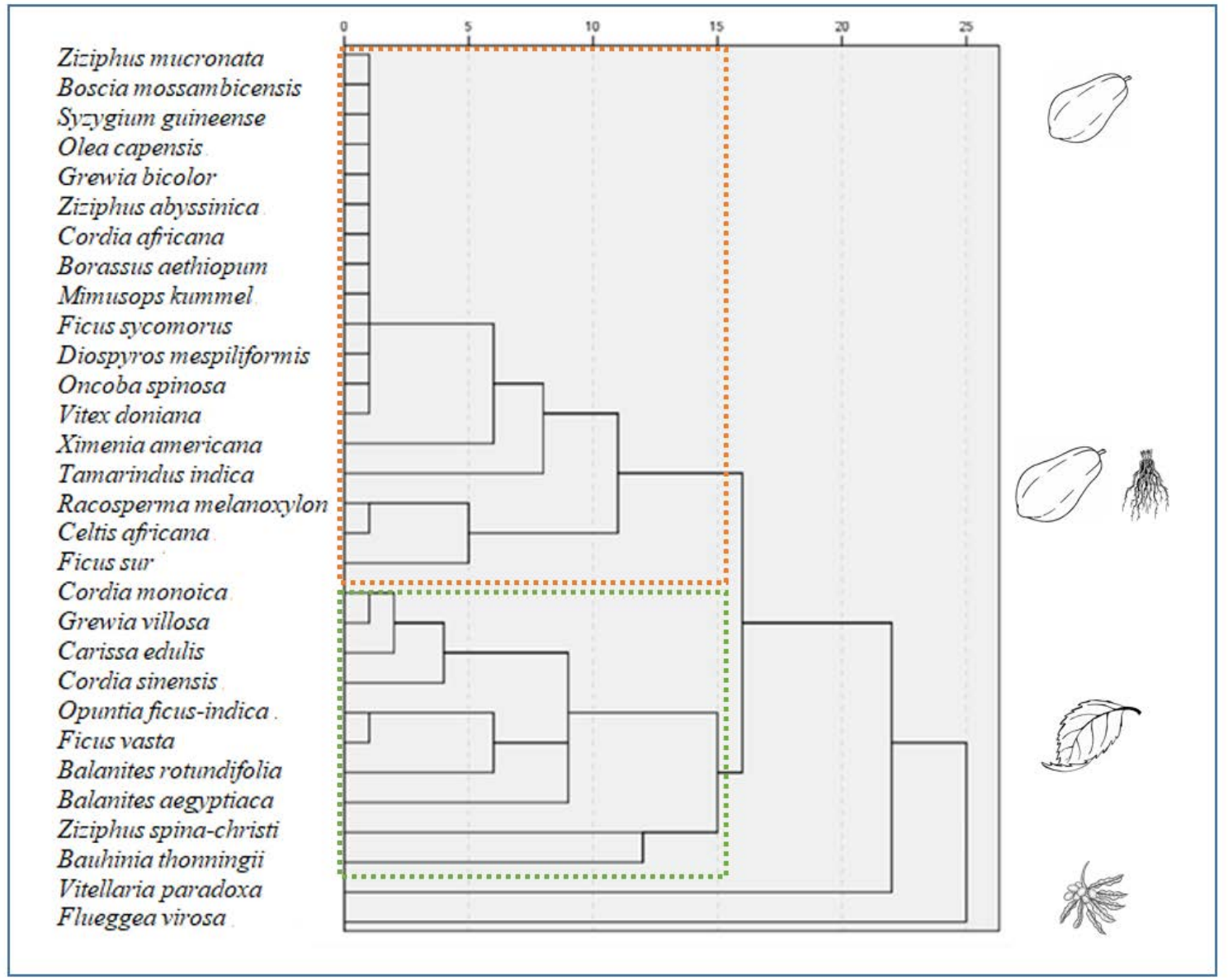

Figure 2. Dendrogram showing the classification of wild edible tree species based on the plant part used by local communities. The horizontal axis represents the distance or dissimilarity between clusters, and the vertical axis represents the species and clusters.

WETs were also clustered into three different groups and two independent species when analyzed based on the mode of consumption: raw, cooked or preserved (Figure 3). The respondents indicated that the 22 species in the first main group (Figure 3) were consumed as raw fruit. Within this group, Tamarindus indica, Vitex doniana, Racosperma melanoxylon and Bauhinia thonningii fruit were also preserved for future use. The fruit of the four species in the second main group were consumed raw and when cooked. However, Carissa edulis was a unique species in this group because the fruit of this species was also preserved for future use. In the third main group, Flueggea virosa and Balanites rotundifolia were consumed raw and when cooked, and they were sometimes preserved for future use. The fruit of Balanites aegyptiaca, which was classified as an independent species, was used raw, cooked and also preserved for future use, and Vitellaria paradoxa fruit was used as a form of fat. 


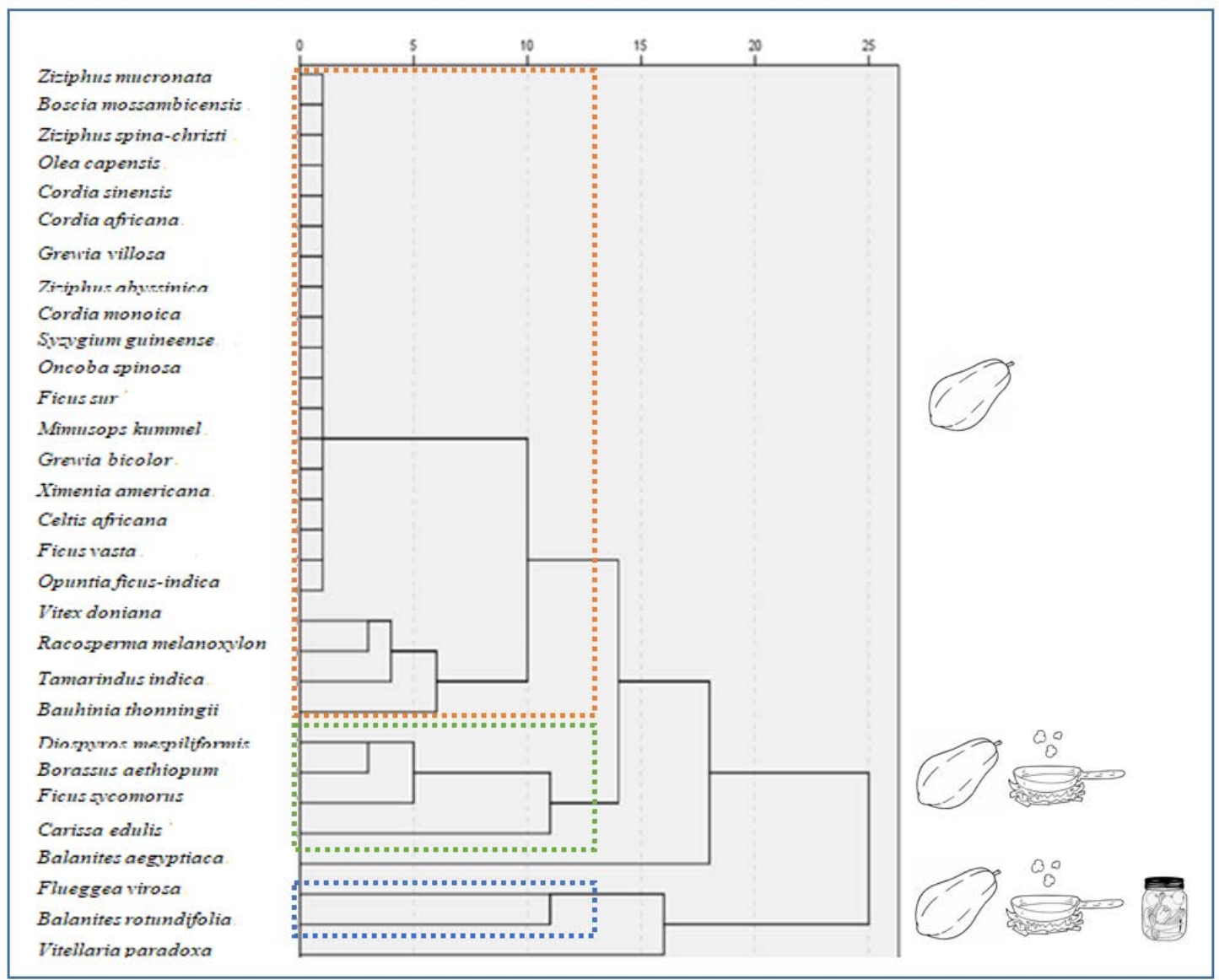

Figure 3. Dendrogram showing the classification of wild edible tree species based on the type of use or consumption by local communities. The horizontal axis represents the distance or dissimilarity between clusters, and the vertical axis represents the species and clusters. Red dashed line, fruit consumed raw; green dashed line, fruit consumed raw and cooked; blue dashed line, fruit consumed raw, cooked and preserved.

\subsection{Seasonality of Wild Edible Tree Species and Shortage Periods}

Periods of food shortage and the availability of food harvested from WETs strongly varied among regions (Chi square test; $p<0.05$ ). The critical periods of food shortage for most of regions were May, June, July and August. However, in Gambella, food shortages occurred for most of the months over the year. Also in this region, reported by the respondents, the food shortages in March, April and May were higher than that of the other months (Figure 4a). The respondents in Gambella region suggested that WETs could potentially provide them with enough food to make up for the shortage of food from conventional agricultural crops during these periods (Figure 4b). The Oromia region had the fewest months with food shortages. Furthermore, food shortages in South Nations, Nationalities, and Peoples Region (SNNPR) were reported, by respondents, more frequently for February than for other months. Although the impact varied across regions, the data also indicated that the availability of food in all the studied regions was reduced during August, September and October, indicating that WETs did make up for this shortfall during this period (Figure $4 b$ ). 


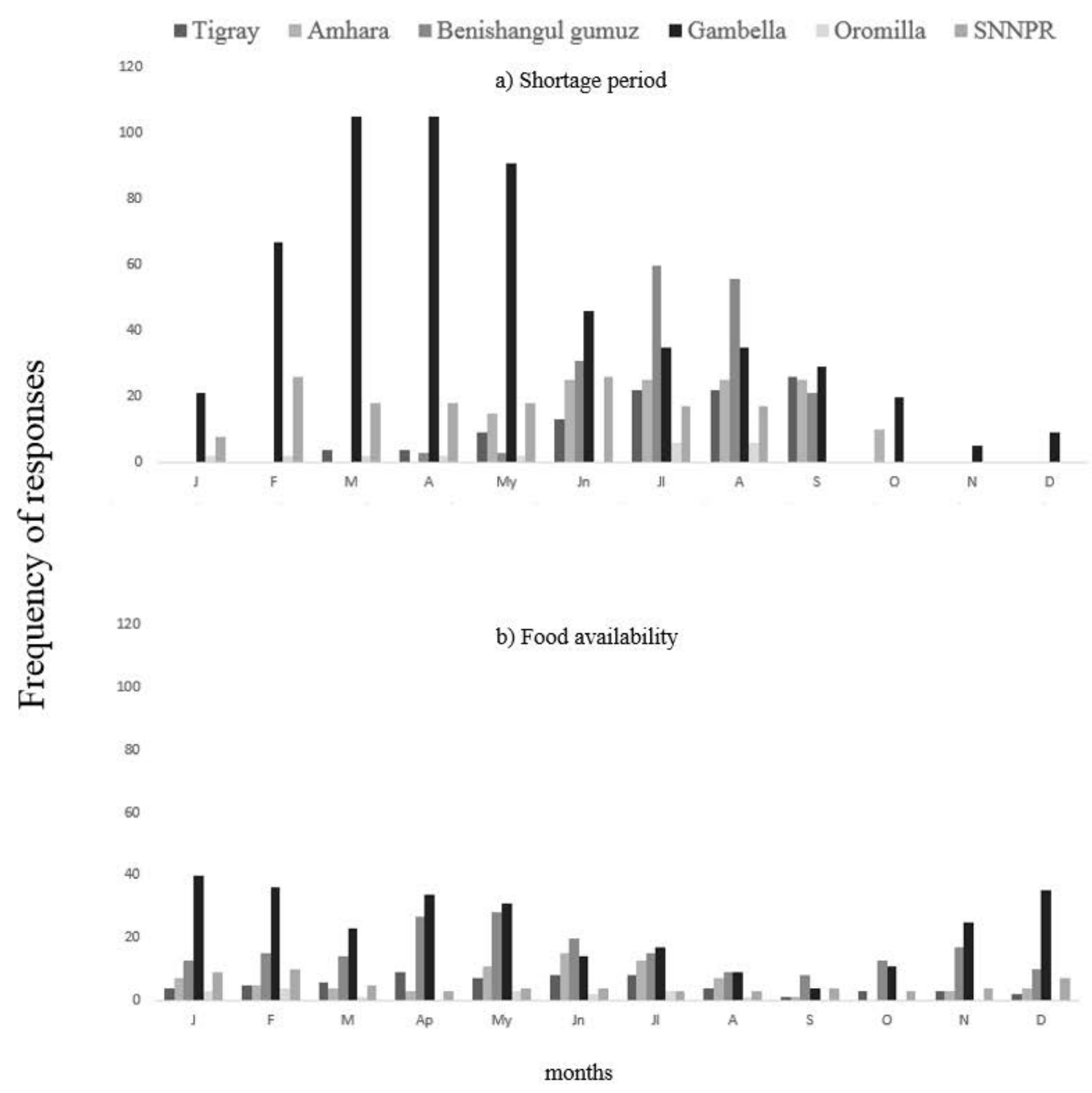

Figure 4. Seasonality of food shortage (a) and availability of WETs (b) in the study regions, Ethiopia. $\mathrm{J}=$ January, $\mathrm{F}=$ February, $\mathrm{M}=$ March, $\mathrm{A}=$ April, My = May, Jn = June, $\mathrm{Jl}=$ July, A = August, $\mathrm{S}=$ September, $\mathrm{O}=$ October, $\mathrm{N}=$ November and $\mathrm{D}=$ December. Frequency: frequency of positive answers from respondents regarding specific questions about periods of food shortage and the availability of food from the 15 most frequently used WETs.

Consumption patterns and plant part uses varied by regions (Chi square test; $p<0.05$ ). Although the fruit of WETs were the most frequently used plant part in all the regions, far more respondents indicated that they consumed the fruit of WETs in the Gambella region than that in other regions (Figure 5a). In Tigray and SNNP regions, the number of respondents that indicated that they consumed WETs as leafy vegetables was higher than that in other regions, and more respondents in the Benishangul Gumuz region indicated that they consumed the roots of WETs than in other regions.

Although the fruit of WETs was usually consumed raw in all regions, fruit was not cooked or preserved in Oromia, Amhara and Tigray regions (Figure 5b). Root and leaf WET forms were also consumed when cooked and preserved in Benishangul Gumuz and SNNP regions, respectively. A greater number of respondents in the Gambella region indicated that they consumed wild fruit, leaves, bark and seed than respondents in other regions. People in the Gambella region consumed plant parts when raw, cooked (usually leave) or when preserved. 


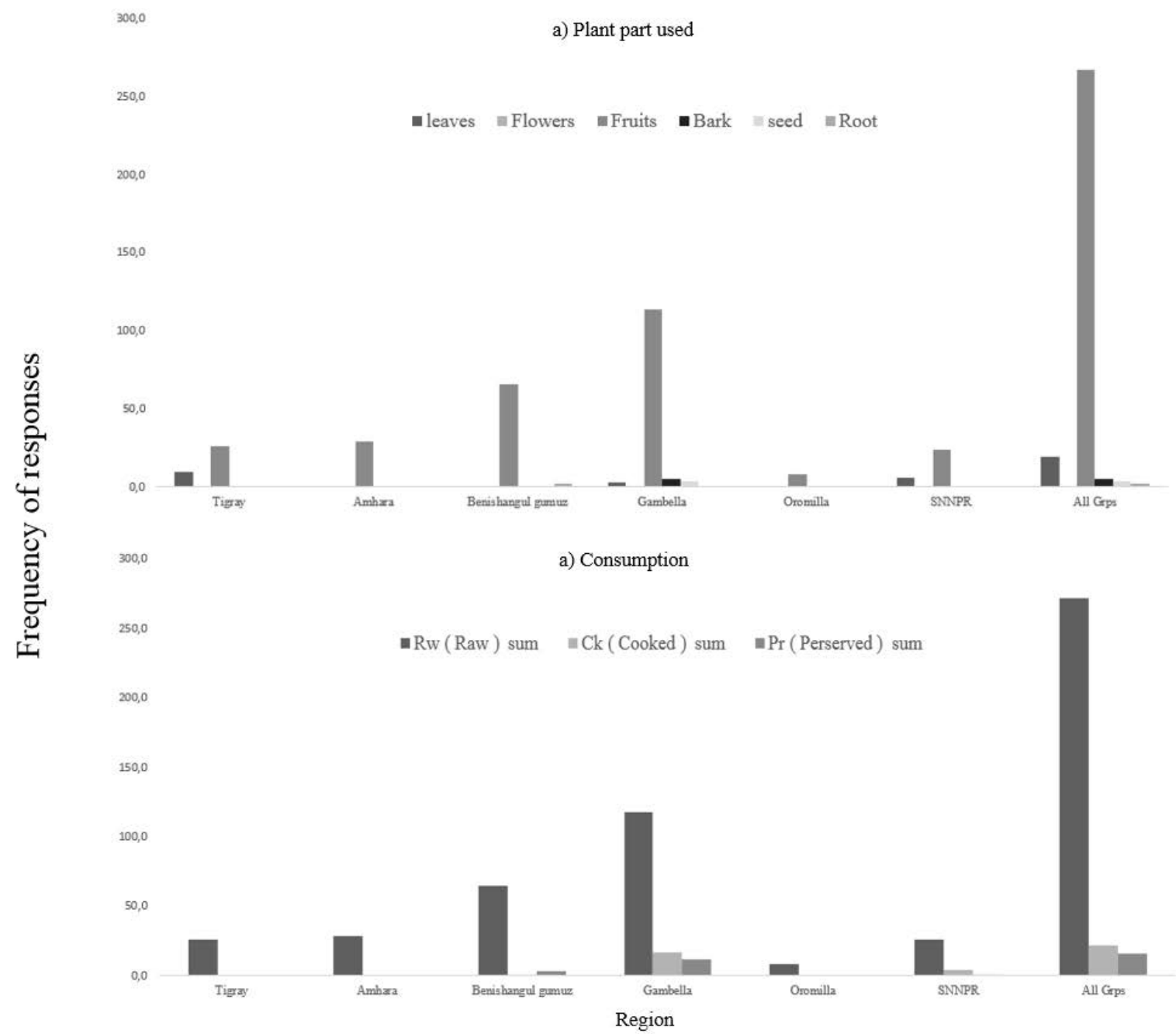

Figure 5. Plant parts used (a) and consumption form per region (b) of wild edible tree species in the study areas. Frequency: the frequency of positive answers from respondents regarding specific questions about the plant part used and their consumption of the 15 most frequently used WETs $(n=$ 280; total frequency for the 15 most frequent species from focus group discussions).

\subsection{Threats and Conservation Status}

Based on the results from the respondents' view, most of the evaluated threats showed a significant influence (Kruskal-Wallis test, $p<0.05$; Table 4 ) on WETs in the studied regions. Only grazing showed no influence on the conservation status of WETs $(p>0.05)$. The species were differently affected by the threats $(p=0.00)$. Individually, the species most threatened by all the threat factors was Celtis africana $(p<0.05)$. Pest and diseases, tree age and soil fertility were significant threats for Ziziphus spina-christi, Balanites aegyptiaca and Tamarindus indica tree species (Mann-Whitney $\mathrm{U}$ test; $p<0.05$; Table 4). 
Table 4. Effects of threats on the 15 most frequently used WETs based on the frequency $(n=494)$ of the responses for each threat: mean risk value for each threat categorized by respondents on a scale from 0 to 4 when considering the impact of each threat on each WETs. C: clearing of the forest, F: fire, G: grazing, T: timber harvesting, L: leaf harvesting, Fr: fruit harvesting, Fl: flower harvesting, R: root harvesting, B: bark harvesting, C: charcoal making, P: pest infestation, D: drought, AG: age of the tree, S: soil fertility condition of the site and O: others.

\begin{tabular}{|c|c|c|c|c|c|c|c|c|c|c|c|c|c|c|c|c|}
\hline Name & Frequency & $\mathrm{C}$ & $\mathbf{F}$ & G & $\mathbf{T}$ & $\mathbf{L}$ & Fr & Fl & $\mathbf{R}$ & B & $\mathrm{C}$ & $\mathbf{P}$ & $\mathbf{D}$ & $\mathbf{A}$ & $\mathbf{S}$ & $\mathbf{O}$ \\
\hline Ziziphus spina-christi & 65 & 2.05 & 1.57 & 1.83 & 2.11 & 1.55 & 1.86 & 1.48 & 1.57 & 1.54 & 1.68 & 2.28 & 1.98 & 2.35 & 2.58 & 1.26 \\
\hline Tamarindus indica & 54 & 1.96 & 1.80 & 1.78 & 1.52 & 1.30 & 1.76 & 1.37 & 1.33 & 1.30 & 1.31 & 2.65 & 2.11 & 2.15 & 2.28 & 0.43 \\
\hline Balanites aegyptiaca & 53 & 2.06 & 1.57 & 1.79 & 1.77 & 1.47 & 1.98 & 1.28 & 1.40 & 1.47 & 2.09 & 2.25 & 1.60 & 2.00 & 2.23 & 0.96 \\
\hline Ximenia americana & 45 & 1.82 & 1.60 & 1.73 & 1.40 & 1.27 & 1.87 & 1.07 & 1.24 & 1.24 & 1.38 & 2.13 & 1.62 & 1.47 & 2.29 & 0.67 \\
\hline Carissa edulis & 44 & 1.77 & 1.77 & 1.50 & 1.09 & 1.18 & 1.68 & 1.07 & 1.27 & 1.23 & 1.18 & 1.75 & 1.41 & 1.80 & 1.91 & 0.68 \\
\hline Grewia villosa & 29 & 2.21 & 1.66 & 2.07 & 1.86 & 1.79 & 1.93 & 1.62 & 2.03 & 2.00 & 1.79 & 2.69 & 1.83 & 1.83 & 2.79 & 0.93 \\
\hline Ficus sycomorus & 31 & 1.86 & 2.07 & 1.43 & 1.68 & 1.32 & 2.11 & 1.50 & 1.43 & 1.46 & 1.32 & 2.18 & 1.64 & 2.00 & 1.68 & 0.75 \\
\hline Syzygium guineense & 31 & 2.36 & 1.67 & 1.58 & 1.33 & 1.04 & 1.33 & 1.13 & 1.13 & 1.00 & 1.17 & 2.08 & 2.46 & 2.58 & 2.63 & 0.00 \\
\hline Ficus vasta & 26 & 1.87 & 1.17 & 1.87 & 1.43 & 1.39 & 1.61 & 1.17 & 1.35 & 1.52 & 1.30 & 1.52 & 1.35 & 1.35 & 1.43 & 1.22 \\
\hline Opuntia ficus-indica & 20 & 1.95 & 1.20 & 1.65 & 1.15 & 1.35 & 1.65 & 1.05 & 1.40 & 1.25 & 1.10 & 2.00 & 1.25 & 1.80 & 1.25 & 1.50 \\
\hline Cordia monoica & 20 & 2.15 & 1.00 & 1.55 & 1.50 & 1.45 & 1.50 & 1.15 & 1.50 & 1.30 & 1.50 & 1.60 & 1.35 & 1.40 & 1.45 & 1.50 \\
\hline Bauhinia thonningii & 22 & 2.21 & 1.89 & 1.74 & 1.53 & 1.68 & 2.21 & 1.47 & 1.47 & 1.63 & 2.05 & 2.26 & 2.00 & 2.42 & 2.47 & 1.47 \\
\hline Mimusops kummel & 18 & 1.83 & 2.44 & 1.72 & 1.28 & 1.06 & 2.06 & 1.11 & 1.44 & 1.28 & 1.17 & 1.78 & 2.06 & 2.11 & 1.94 & 0.17 \\
\hline Diospyros mespiliformis & 18 & 1.44 & 2.17 & 1.33 & 0.94 & 1.22 & 2.11 & 1.11 & 1.00 & 1.00 & 1.00 & 2.06 & 1.61 & 1.33 & 1.78 & 0.00 \\
\hline Celtis africana & 18 & 1.83 & 1.61 & 1.89 & 2.11 & 1.83 & 2.28 & 2.33 & 2.67 & 2.67 & 2.28 & 2.39 & 2.44 & 2.78 & 2.44 & 2.06 \\
\hline Kruskal-Wallis ( $p$ value) & & 0.00 & 0.00 & 0.14 & 0.00 & 0.00 & 0.01 & 0.00 & 0.00 & 0.00 & 0.00 & 0.00 & 0.00 & 0.00 & 0.00 & 0.00 \\
\hline
\end{tabular}


According to the respondents' view, the regeneration status of different species also differed significantly (Table 5; Chi square test; $p<0.05$ ). Ziziphus spina-christi, Balanites aegyptiaca, Ximenia americana and Tamarindus indica showed the highest regeneration values (Figure 6). Although affected by different factors (Table 4), the perception of local people was positive regarding the regeneration of most WETs, except for Celtis africana, Opuntia ficus-indica and Diospyros mespiliformis, which were considered to have a relatively lower regeneration status respectively in their order.

Table 5. Chi square test results for regeneration status, ease of locating and conservation practices for WETs in the study areas.

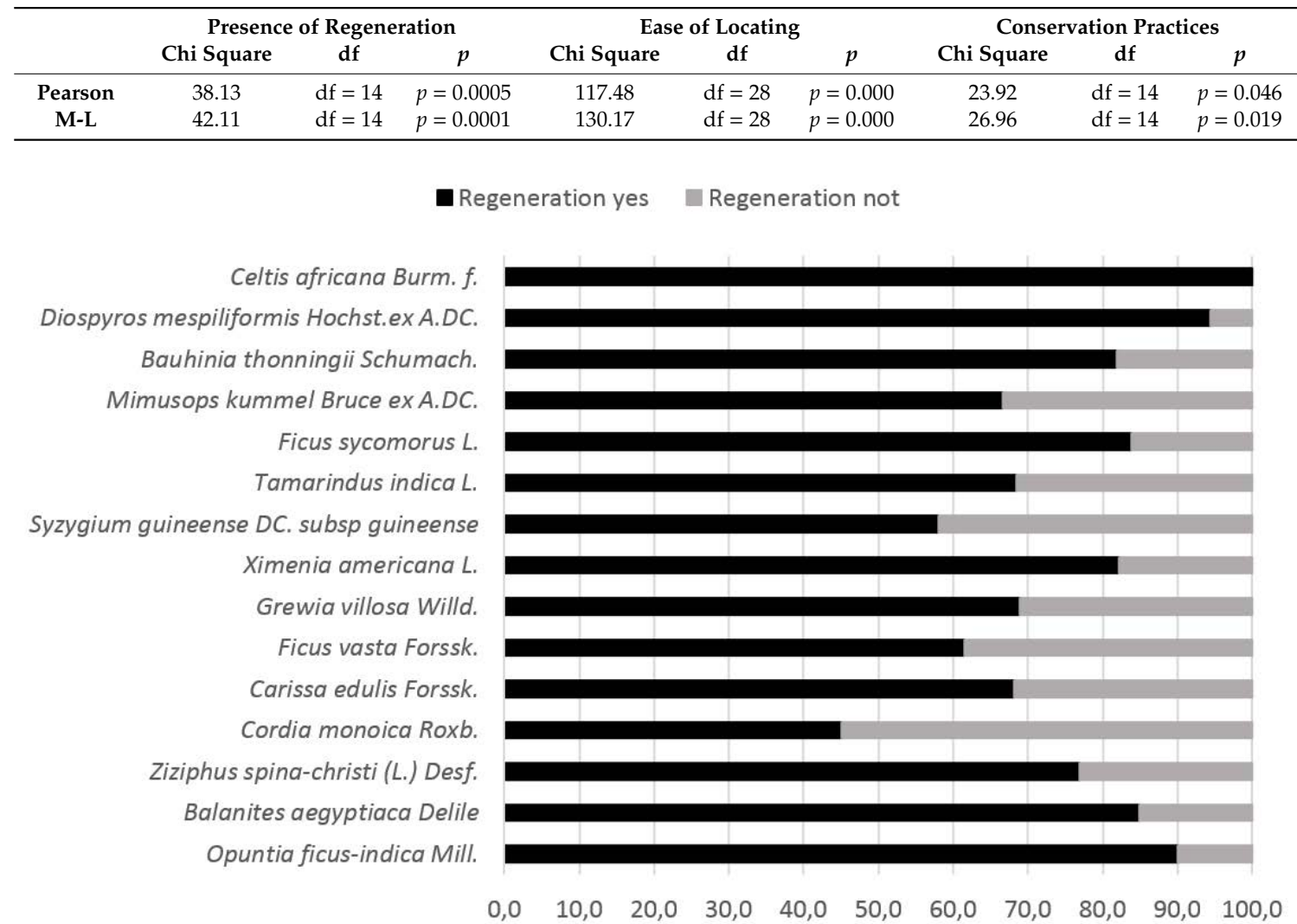

Figure 6. Regeneration status of the 15 wild edible tree species based on the responses from key informants in the study regions.

The ease of locating WETs was also significantly different $(p<0.05)$ depending on the species (Table 5). Based on the perception of the local people, Celtis africana was the most stable species followed by Ficus sycomorus, Bauhinia thonningii, Diospyros mespiliformis, Tamarindus indica and Balanites aegyptiaca, indicating these species were easily located in their locality. Among the key informants, $94.4 \%$ indicated that the ease of locating C. africana was the same as that in previous years. By contrast, Opuntia ficus-indica and Cordia monoica were perceived to be the most difficult WETs to locate compared with previous years (Figure 7a). 

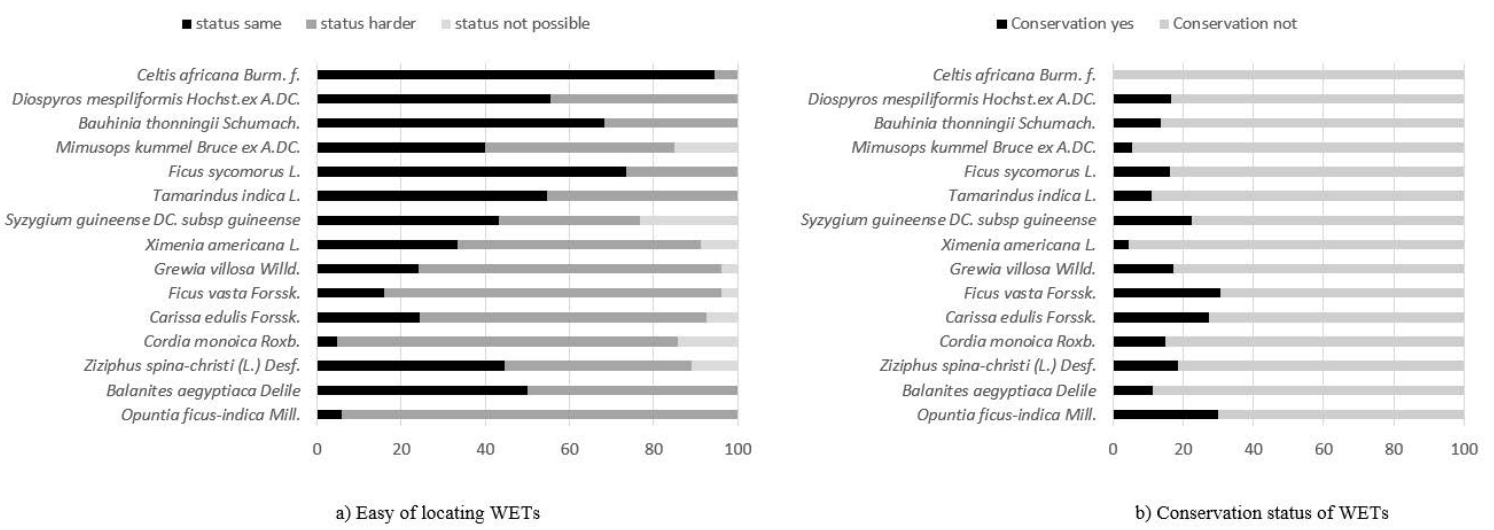

Figure 7. Values indicating the ease of locating WETs and access to these species (a), and their conservation status (b) in the studied areas. Status same: species easily located. Status harder: species harder to locate than previous years. Status not possible: not possible to locate species. Conservation: the percentage of answers indicating the existence of conservation practices by the local people for a specific WET.

The conservation status of WETs differed significantly among species (Chi square test; $p<0.05$ ), with Carissa edulis, Ficus vasta and Opuntia ficus-indica showing higher conservation values than that of the other species (Figure $7 \mathrm{~b}$ ), indicating the conservation practice for these species by the local communities. In this case, the conservation practices considered by the local farmers included the deliberately leaving of trees on their farm land and sometimes planting of important wild edible trees in their garden.

\section{Discussion}

\subsection{Wild Edible Tree Species}

Our current knowledge of wild edible species in Ethiopia has usually been derived from small-scale case studies [23]. In this research, we included representative regions with different ethnic compositions from the dryland parts of the country. We identified a total of 88 indigenous wild edible plants (WEPs), of which 52 species (56\%) were WETs, and 30 of these 52 species were considered by respondents to be commonly consumed by the community, and they were considered to be the most useful species among those listed for the studied regions. The number of WEPs reported in this study was relatively low compared with the number of species documented in previous studies carried out by [33] and [34] in southern Ethiopia. The lower number of WEPs found in the present study may be associated with differences in local traditions and customs relating to the use of wild plants in different parts of the country. Thus, this may reflect social variations in nutrition, attitudes and preferences towards wild food sources. Hence, it also explains differences in agroecology in different parts of the country.

Our results identified the existence of similar cultural practices and knowledge regarding plant parts used and the consumption pattern of WETs among different local communities in Ethiopia. Based on the social perception of respondents, fruit was the main food resource obtained from the most frequently used WETs in our survey, which agrees with findings reported by a previous study [35]. Fruit is mainly consumed raw because, in general, the storage conditions are not suitable for storing fruit for consumption during periods of food scarcity. Leaves throughout, bark, root and seed of some WETs are also commonly consumed by respondents, such as Balanites aegyptiaca, Flueggea virosa and Vitellaria paradoxa. Leaves, bark and roots of these species can also be preserved to complement the diet during months of food shortage in the dryland areas of Ethiopia. Even the oil from some fruit and seeds is used to prepare butter, supplementing the diet with additional calories. The role played by these kinds of WETs and WEPs was previously highlighted as supplementary and used as seasonal food sources by different communities $[23,35,36]$ in some areas of the country as a way of 
combating food insecurity. Despite the importance of WETs in the study area, these tree species have generally been overlooked compared with domesticated plant food sources [23]. Our survey provided a good opportunity for ethnobotanical research of Ethiopian WETs because we were able to obtain ethnographic data directly from local communities, including observations on food culture and botany, plus field observations of different agroecological practices in rural areas where WETs are traditionally used on a daily basis.

\subsection{Seasonality of Wild Edible Tree Species and Food Shortage Periods}

In Ethiopia, products from WETs are generally collected for subsistence use $[34,37,38]$ mainly because the production of edible parts, such as fruit, is seasonal and, therefore, can only be gathered for a short period of time. The fruit harvesting season and uses vary from place to place, even from species to species. This is due to climatic and intraspecific variations. In Ethiopia, seasonal food shortages are a common phenomenon and occur mainly from July to September [39] when storage bins have been emptied and the new crop is not yet ready for harvesting. Our survey revealed that WETs are commonly used during periods of food shortage, seasonally during periods of food scarcity and to add variety to the diet. The extent to which WEPs are used also varied with respect to season. For example, in most parts of the regions surveyed, local respondents reported that the food shortage period occurred in May, June, July and August. However, rural communities from Gambella reported March, April and May as the period when food shortages were most severe. In line with our results, other studies have also indicated that during these periods of food shortage, local communities depend on WETs [33,34,40,41].

The survey results also revealed that some WETs are only consumed during periods of famine, such as Opuntia ficus-indica, Carissa edulis and Ximenia americana in the Amhara region and Syzygium guineense and Carissa edulis in the Oromia region. This might be because these species are only used to supplement the normal diets of many rural people [42]. The respondents in this study indicated that most of the WETs have multiple edible uses. This diverse use of wild plants demonstrates that the indigenous people have a close relationship with local biological resources and that their lives are based on the use of diverse plant species [36]. Indeed, trees have been used as a source of food and medicine since time immemorial and they have become an integral part of the culture of the society throughout the country [43].

\subsection{Threats and Conservation}

Many threats affecting WETs are similar to those that affect other biodiversity resources in Ethiopia [44]. We evaluated threats affecting the 15 WETs reported most frequently used by local communities in the studied regions and their conservation status. The highest values/ranks were assigned to different WETs, including Celtis africana, Ziziphus spina-christi, Balanites aegyptiaca and Tamarindus indica. The respondents indicated that these plants are exploited more for their nonfood uses than for their food values. Overharvesting of these WETs to obtain fuel wood, medicine and for fencing, construction and forage purposes is aggravating the degradation status of these species in all the study areas. Moreover, the species were also affected by pests and diseases, which might have a direct influence on their degradation status. Diseases and pests start to occur when local communities change from a pastoral to an agropastoral way of life [33]. These factors can also limit the benefits that can be derived from the management and conservation of wild edible food plants in the dryland part of the country.

In general, owing to the diversity of WETs, conservation and management strategies are needed to achieve food security from the use of forest resources. Actions for the conservation and management of wild edible species include recognition of the limitations and the need to search for a way forward. Although all species with various uses deserve attention [45], the most highly valued food tree species in this study, Celtis africana, Ziziphus spina-christi, Balanites aegyptiaca and Tamarindus indica, should be prioritized when considering management strategies, their conservation and domestication. Moreover, overexploitation of plant parts (i.e., roots, leaves, bark and wood) could cause plant death or low plant 
productivity. Thus, unsustainable harvesting and product utilization should also be considered because these can cause the depletion of WETs in their natural habitats. Furthermore, their conservation should be encouraged and enhanced through the application of in situ and ex situ conservation programs, giving special consideration to those species currently used by local communities in different parts of the country.

\section{Conclusions}

This study attempts to provide baseline information that can be used as part of a management strategy for sustainable natural resource utilization in addition to documenting WETs in Ethiopia. The findings are based on the social perception of local communities who reported the actual use and demand for species found in the studied regions. From their responses, we were able to highlight the existence of valuable WETs and details relating to their utilization in the lowland parts of the country. The study also shows that WETs play a major role as a source of food and are characterized by a very high frequency of consumption by locals and contribute significantly to their livelihood through various uses. Such uses demonstrate that local people have a close relationship with their local biological resources. However, a range of factors are now affecting the WETs in Ethiopia, indicating that conservation practices should be enhanced through the application of management strategies, giving special consideration to those species currently used by local communities. Hence, there is also an urgent need for research studies on WETs to promote their use as part of a strategy to improve the food security, nutrition and livelihoods of rural communities throughout the country. Thus, the experiential knowledge of different ethnic groups should be documented because it is important for the development and conservation of important tree resources.

Author Contributions: All authors have read and agreed to the published version of the manuscript. Conceptualization, P.M.-P. and D.A.; methodology, D.A., P.M.-P. and T.D.; software, P.M.-P.; validation, P.M.-P.; formal analysis, P.M.-P.; investigation, P.M.-P. and D.A.; data curation, M.S.A.; writing—original draft preparation, M.S.A.; writing-review and editing, P.M.-P. and T.D.

Funding: This research and the APC were funded by the Spanish Agency for International Development Cooperation (AECID), PCI C/032533/10. Check carefully that the details given are accurate and use the standard spelling of funding agency names at https://search.crossref.org/funding, any errors may affect your future funding.

Acknowledgments: We would like to express our gratitude to the key informants and to the people involved in the focus groups discussion who provided the information from local communities. The research was partially funded by Spanish Agency for International Development Cooperation project (Sustfungi_Eth; 2017/ACDE/002094).

Conflicts of Interest: The authors declare no conflict of interest.

\section{References}

1. Javier, T.; Manuel, P.; Ramon, M. Ethnobotanical review of wild edible plants of Slovakia. Bot. J. Linn. Soc. 2006, 152, 27-71. [CrossRef]

2. Lachat, C.; Raneri, J.E.; Smith, K.W.; Kolsteren, P.; Van Damme, P.; Verzelen, K.; Penafiel, D.; Vanhove, W.; Kennedy, G.; Hunter, D.; et al. Dietary species richness as a measure of food biodiversity and nutritional quality of diets. Proc. Natl. Acad. Sci. USA 2018, 115, 127-132. [CrossRef] [PubMed]

3. Black, R.E.; Victora, C.G.; Walker, S.P.; Bhutta, Z.A.; Christian, P.; De Onis, M.; Ezzati, M.; Grantham-Mcgregor, S.; Katz, J.; Martorell, R.; et al. Maternal and child under nutrition and overweight in low-income and middle-income countries. Lancet 2013, 382, 427-451. [CrossRef]

4. De Caluwé, E.; Halamová, K.; Van Damme, P. Adansonia digitata L.-A review of traditional uses, phytochemistry and pharmacology. Afrika Focus 2010, 23, 10-51. [CrossRef]

5. Powell, B.; Thilsted, S.H.; Ickowitz, A.; Termote, C.; Sunderland, T.; Herforth, A. Improving diets with wild and cultivated biodiversity from across the landscape. Food Secur. 2015, 7, 535-554. [CrossRef]

6. Termote, C.; Meyi, M.; Ndjango, J.; Van Damme, P.; Dhed'a, D.B. Use and Socioeconomic Importance of Wild Edible Plants in Tropical Rainforest Around Kisangani District, tshopo, DR Congo. In Systematics and Conservation of African Plants; Van der Burgt, X., Ed.; Royal Botanic Gardens: Kew, UK, 2009; pp. 415-425. 
7. Mengistu, F.; Hager, H. Wild edible fruit species cultural domain, informant species competence and preference in three districts of Amhara region, Ethiopia. Ethnobot. Res. Appl. 2008, 6, 487-502. [CrossRef]

8. Ickowitz, A.; Rowland, D.; Powell, B.; Salim, M.A.; Sunderland, T. Forests, trees, and micronutrient-rich food consumption in Indonesia. PLoS ONE 2016, 11, 1-15. [CrossRef]

9. Rowland, D.; Blackie, R.R.; Powell, B.; Djoudi, H.; Vergles, E.; Vinceti, B.; Ickowitz, A. Direct contributions of dry forests to nutrition: A review. Int. For. Rev. 2015, 17, 45-53. [CrossRef]

10. Termote, C.; Bwama Meyi, M.; Dhed'a Djailo, B.; Huybregts, L.; Lachat, C.; Kolsteren, P.; Van Damme, P. A biodiverse rich environment does not contribute to a better diet: A case study from DR Congo. PLoS ONE 2012, 7. [CrossRef]

11. Ickowitz, A.; Powell, B.; Salim, M.A.; Sunderland, T.C.H. Dietary quality and tree cover in Africa. Glob. Environ. Chang. 2014, 24, 287-294. [CrossRef]

12. Johnson, K.B.; Jacob, A.; Brown, M.E. Forest cover associated with improved child Health and nutrition: Evidence from the Malawi Demographic and Health Survey and satellite data. Glob. Health Sci. Pract. 2013, 1, 237-248. [CrossRef]

13. Beluhan, S.; Ranogajec, A. Chemical composition and non-volatile components of Croatian wild edible mushrooms. Food Chem. 2011, 124, 1076-1082. [CrossRef]

14. Vinceti, B.; Termote, C.; Thiombiano, N.; Agúndez, D.; Lamien, N. Food tree species consumed during periods of food shortage in Burkina faso and their threats. For. Syst. 2018, 27. [CrossRef]

15. Agúndez, D.; Douma, S.; Madrigal, J.; Gómez-Ramos, A.; Vinceti, B.; Alía, R.; Mahamane, A. Conservation of food tree species in Niger: Towards a participatory approach in rural communities. For. Syst. 2016, 25. [CrossRef]

16. Atato, A.; Wala, K.; Batawila, K.; Lamien, N.; Akpagana, K. Edible wild fruit highly consumed during food shortage period in Togo: State of knowledge and conservation status. J. Life Sci. 2011, 5, 1046-1057.

17. Faye, M.D.; Weber, J.C.; Abasse, T.A.; Boureima, M.; Larwanou, M.; Bationo, A.B.; Diallo, B.O.; Sigué, H.; Dakouo, J.M.; Samaké, O.; et al. Farmers' preferences for tree functions and species in the west African Sahel. For. Trees Livelihoods 2011, 20, 113-136. [CrossRef]

18. Jaenicke, H.; Hoschle-Zeledon, I. Strategic Framework for Underutilized Plant Species Research and Development; With special reference to Asia and the Pacific, and to Sub-Saharan Africa; ICUC, Colombo and Global Facilitation Unit for Underutilized Species: Rome, Italy, 2006; p. 33.

19. Melaku, E.; Ewnetu, Z.; Teketay, D. Non-timber forest products and household incomes in Bonga forest area, southwestern Ethiopia. J. For. Res. 2014, 25, 215-223. [CrossRef]

20. Sardeshpande, M.; Shackleton, C. Wild edible fruits: A systematic review of an under-researched multifunctional non-timber forest product. Forests 2019, 10, 467. [CrossRef]

21. Addis, G.; Urga, K.; Dikasso, D. Ethnobotanical study of edible wild plants in some selected districts of Ethiopia. Hum. Ecol. 2005, 33, 83-118. [CrossRef]

22. Friis, B.; Demissew, S.; Breugel, P. Atlas of the Potential Vegetation of Ethiopia; The Royal Danish Academy of Sciences and Letters: Copenhagen, Denmark, 2010; p. 307.

23. Lulekal, E.; Asfaw, Z.; Kelbessa, E.; Van Damme, P. Wild edible plants in Ethiopia: A review on their potential to combat food insecurity. Afrika Focus 2011, 24. [CrossRef]

24. Asfaw, Z. The Future of Wild Food Plants in Southern Ethiopia: Ecosystem Conservation Coupled with Enhancement of the Roles of Key Social Groups. Acta Hortic. 2009, 806, 701-708. [CrossRef]

25. Birara, E.; Mequanent, M.; Samuel, T. Assessment of Food Security Situation in Ethiopia: A Review. Asia J. Agric. Res. 2015, 9, 55-68. [CrossRef]

26. Parmesan, C. Ecological and Evolutionary Responses to Recent Climate Change. Annu. Rev. Ecol. Evol. Syst. 2006, 37, 637-699. [CrossRef]

27. Feyssa, D.H.; Njoka, J.T.; Asfaw, Z.; MM, N. Seasonal availability and consumption of wild edible plants in semiarid Ethiopia: Implications to food security and climate change adaptation. J. Hortic. For. 2011, 3, 138-149.

28. Alves, R.R.N.; Rosa, I.M.L. Biodiversity, traditional medicine and public health: Where do they meet? J. Ethnobiol. Ethnomed. 2007, 3, 1-9. [CrossRef] [PubMed]

29. Tabuti, J.R.S.; Kukunda, C.B.; Kaweesi, D.; Kasilo, O.M.J. Herbal medicine use in the districts of Nakapiripirit, Pallisa, Kanungu, and Mukono in Uganda. J. Ethnobiol. Ethnomed. 2012, 8, 1-15. [CrossRef] [PubMed] 
30. Bharucha, Z.; Pretty, J. The roles and values of wild foods in agricultural systems. Philos. Trans. R. Soc. B 2010, 365, 2913-2926. [CrossRef]

31. Sarantakos, S. Social Research; Macmillan Press Ltd.: London, UK, 1998; p. 488.

32. Eshete, A.; Sterck, F.; Bongers, F. Diversity and production of Ethiopian dry woodlands explained by climateand soil-stress gradients. For. Ecol. Manag. 2011, 261, 1499-1509. [CrossRef]

33. Assefa, A.; Abebe, T. Wild Edible Trees and Shrubs in the Semi-arid Lowlands of Southern Ethiopia. J. Sci. Dev. 2010, 1, 5-19.

34. Balemie, K.; Kebebew, F. Ethnobotanical study of wild edible plants in Derashe and Kucha Districts, South Ethiopia. J. Ethnobiol. Ethnomed. 2006, 2. [CrossRef]

35. Teketay, D.; Senbeta, F.; Maclachlan, M.; Bekele, M.; Barklund, P. Edible Wild Plants in Ethiopia; Addis Ababa University Press: Addis Ababa, Ethiopia, 2010; p. 575.

36. Awas, T.; Asfaw, Z.; Nordal, I.; Demissew, S. Ethnobotany of Berta and Gumuz people in western Ethiopia. Biodiversity 2010, 11, 45-53. [CrossRef]

37. Fentahun, M.T.; Hager, H. Exploiting locally available resources for food and nutritional security enhancement: Wild fruits diversity, potential and state of exploitation in the Amhara region of Ethiopia. Food Secur. 2009, 1, 207-219. [CrossRef]

38. Potentials and Constraints of Mushroom Production in Ethiopia; A Paper Presented at the National Mushroom Conference: Addis Ababa, Ethiopia. Available online: http://kmyb.yolasite.com/resources (accessed on 19 December 2019).

39. Getachew, O. Food Source Diversification: Potential to Ameliorate the Chronic Food Insecurity in Ethiopia. In Proceedings of the Potential of Indigenous Wild Foods, Diana, Kenya, 22-26 January 2001; Kenyatta, C., Henderson, A., Eds.; United States Agency for International Development, 2001. Available online: https: //www.fsnnetwork.org/sites/default/files/indigenous_wild_foods.pdf (accessed on 19 December 2019).

40. Getahun, A. The Role of Wild Plants in the Native Diet in Ethiopia the Level of Plant Lore in Ethiopia. AgroEcosystems 1974, 1, 4556.

41. Wild-food Plants in Southern Ethiopia: Reflections on the Role of 'Famine-Foods' at a Time of Drought. Addis Ababa, Ethiopia. Available online: https://reliefweb.int/report/ethiopia (accessed on 19 December 2019).

42. The Hidden Harvest. In Seedling, the Quarterly Newsletter of Genetic Resources Action, International (GRAIN). Available online: https://www.grain.org/en/article/318-the-hidden-harvest (accessed on 19 December 2019).

43. Kassaye, K.; Amberbir, A.; Getachew, B.; Mussema, Y. A historical overview of traditional medicine practices and policy in Ethiopia. Ethiop. J. Health Dev. 2006, 20, 127-134. [CrossRef]

44. Ethiopia's Fifth National Report to the Convention on Biological Diversity. Available online: https: //www.cbd.int/doc/world/et/et-nr-05-en.pdf (accessed on 17 December 2019).

45. Mamounata, B.; Moumouni, N.; Josephine, Y. Strategy of Conservation and Protection of Wild Edible Plants Diversity in Burkina Faso. Anadolu J. AARI 2017, 27, 82-90.

(C) 2020 by the authors. Licensee MDPI, Basel, Switzerland. This article is an open access article distributed under the terms and conditions of the Creative Commons Attribution (CC BY) license (http://creativecommons.org/licenses/by/4.0/). 